\title{
Research of Operating Mode for Corporate University
}

\author{
Niu Lichun \\ Xijing University, \\ Shaanxi Xi'an ,China \\ e-mail: 815765002@qq.com
}

\author{
Shang Miao \\ Xijing University, \\ Shaanxi Xi'an ,China \\ e-mail: 445700839@qq.com
}

\begin{abstract}
The corporate universities and enterprise's production practice is the fusion of each other. The corporate university learning content is relatively more specific. The enterprise university learning programs and training products are mostly specificity, customized. The certification effectiveness of corporate university project that has some limitations. College and Enterprise is common in contemporary society. In this article, the enterprise financing pattern are analyzed, and the project management mode of university are studied; The common features of universities and corporations is discussed. The research of operation mode of corporate universities shows that: The financing pattern of corporate universities is the core of the enterprise university operation mechanism; The operating of corporate universities mainly on project management mode; Universities and corporations have common features, and the development of the corporate university is inevitable. The cooperation of corporate universities and the institutions of higher education is very important for our country industry talents training.
\end{abstract}

Keywords-Operating mode; Corporate university; Financing pattern; Management mode; Higher education

\section{INTRODUCTION}

In the modern society, college and enterprise is common. There is great difference between companies and universities in the nature, function and value pursuit. The function of university is passing on culture, cultivating talents. The pursuit of enterprise is to make a profit. Rapid development in science and technology of the century, when companies and universities are integrated together, "corporate university" was born. The vigorous development of the modern enterprise university time is more than ninety. Founded in 1927, general motors' company's first corporate university [1]. China is the first corporate university institute of hisense. The establishment of the institute of hisense marked the boom of Chinese enterprise university founded formally began.

Specific corporate universities and enterprises is combining production practice. Corporate university learning content is relatively more specific. Enterprise of the university of learning project, are mostly specificity, customized training products. Enterprise project at the university of certification effectiveness has some limitations. Scope of business services at the university of also has some limitations. Learning content is given priority to with professional disciplines of higher education, pay attention to the theoretical knowledge of the system. The general principles of higher education emphasizes the professional field. High education provide education program is mostly specificity. Diploma of higher education is the social general certificate of approval. With the vigorous development of the corporate university, university of different enterprises have different development needs. Corporate university learning program provided by the scope of certification is no longer limited to only be recognized within the enterprise. Part of the corporate university hope to cooperate with institutions of higher education, and the opening of a formal recognition degree programs, gain social acceptance in the general certificate. Increase the enterprise of the university of learning value, make employees have a certain general ability, has the ability of continuous employment.

The mode of the corporate university is a lot of. Financing mode and project management mode is the most common.

\section{FINANCING PATTERN ANALYSIS}

At the university of enterprise financing pattern is the core of the enterprise university operation mechanism. To some extent, the concrete operating enterprises financing mode is also at the university of university motivation mechanism. Enterprise of the university of financing pattern has been developing [2]. Enterprise financing mode generally includes sharing internal services at the university of enterprise budget allocation model, a matrix, and the combination of the two models.

\section{A. Self-financing model}

Some corporate universities as parent business unit independent operation. Corporate universities sell yourself. The activities of the corporate universities promote themselves both inside and outside the organization and the role of. Corporate universities pay attention to understanding the needs of the customers and provide customer satisfaction services [3]. Corporate universities also built closely contact with enterprise strategy measure. University of enterprises to raise funds, paid service mode transformation, based on market-oriented business model provides education and training services, this model is also known as "Shared internal services" or "take" in resources. When corporate universities independent operation, tend to adopt the "Shared internal service" mode. If corporate universities cannot better or at a lower cost than external suppliers to provide products or services, then the internal business units can be approved by the company, usually to buy these products or services from other place. Self-raised funds means corporate universities are not fixed budget guarantee, increased pressure on enterprise existence and development of university [4]. Corporate universities want to survive in the competition in the market development, 
we must continue to improve service quality, and constantly learning the advanced experience of the industry. Corporate universities need to be further strengthened enterprise university's market service consciousness and the ability of competition in the market. Corporate universities should not only guarantee the service quality and efficiency, but also the cost effectiveness of services. Corporate universities to strengthen their own irreplaceable core ability and core values. Corporate universities need to make their services more market competitiveness. Therefore, pursuit of excellence in customer service as the key to the success of the model enterprise university.

\section{B. Maternal enterprise budget allocation model}

Most corporate universities has an important strategic position. The function of corporate universities have irreplaceability. Corporate universities through market outsourcing to replace the hard. So most of the enterprise financing mode of the university of still is given priority to with maternal enterprise budget allocation model. For ensuring adequate funding for the stability of the university focus on service matrix can also help enterprise development strategies. Corporate university won't because the pursuit of department interests or lack of funding and affected. Based on the enterprise university's annual budget, parent companies on corporate university funding, and establish and perfect the related system of performance evaluation mechanism and financial audit. Parent company guarantee the quality and efficiency of enterprise operation management at the university of, and to ensure that the enterprise of the university of input and output efficiency.

When learning program, training products offered by corporate universities mainly proprietary knowledge, its scope of certification effectiveness will be limited within the enterprise [5]. Generally in order to encourage employees to autonomous learning and development, enterprises will establish corresponding learning incentive mechanism, enterprise internal certification system, staff development evaluation system and so on. And perfect the relevant regulations, make the staff training, learning performance and employee rank promotion, benefits, career development. Some corporate universities, for example, has established the leadership training system and evaluation system, certification and evaluation results as the mother's subsequent management of training and selecting the important reference basis. Shared internal service model and budget allocations are often combined in the actual operation. In guarantee complete annual plan and matrix enterprises designated task, corporate universities will also to each business unit to provide paid services within our capabilities.

Shared internal services in the actual operation mode and budget allocations are often combined, but not completely to profit as the main purpose. Corporate universities in guarantee complete annual plan and matrix enterprises designated tasks, will also to each business unit to provide paid services within our capabilities. Institute of China telecom training services, for instance, when there are always unplanned service parent business unit training program, and on the basis of enterprise security priority service matrix will be combined with its own strengths and advantages for external customers provide paid services market, this not only enhance the service ability of the university of enterprises, and expand the financing channels, but it is not entirely for-profit.

\section{PROJECT MANAGEMENT PATTERN ANALYSIS}

\section{A. Project management mode}

Corporate universities operating mainly on project management model in general. Learning project needs analysis and research, project planning, budget, audit, project bidding, choose partners, to the project, the selection and training of teachers of curriculum development, learning, performance evaluation, improvement and application promotion project reviews have standard project management processes and specific operation requirements and evaluation criteria. Learning project operation and management of the college, for example, project at the university of enterprise management mode are analyzed.

\section{B. Source of the project}

College mainly undertake the enterprise internal training programs, training program mainly from two aspects: first, planned to undertake projects. Namely undertake from the human resources department and the group's business units entrust training program. Second, the unplanned project independently [6]. The college combined with the enterprise strategy development needs, based on the research of various business departments, according to business development needs, set up independent learning program. School program principle is first meet with the enterprise development strategy is closely related to the business requirements, key support enterprise strategic development at the core of transformation is the most important ability training.

\section{Project operation and management}

The operation of the project management on the basis of the project manager responsibility system. According to the specific implementation of the project management process, the process link includes: the prophase planning, research, and the establishment; Medium-term development, implementation, evaluation, feedback and improvement; The late review, improvement, application and promotion.

Based on field investigations, the strategic development of the enterprise is a line from the production and management problems and needs. According to the importance of screening, screening, and ultimately determine the project after project review. Project review including the meaning of project, project budget, feasibility analysis, specific implementation plan, the audit target effect, etc.

In the project research and development with independent research and development, research and development and other forms of cooperation. Regardless of independent research and development or cooperative research and development, if you need to specify suppliers to complete the project task is to organize project bidding. By the project department to recommend some qualified and strong research and development ability of the industry best suppliers to participate in the project bidding meeting, participate in the bidding meeting and 
educational administration department, comprehensive department, enterprise internal and external experts and so on. And by the expert judges scores, selection, and determine supplier, conclude a contract for the project. Project began to send most is a cooperative research and development, general early orchestrated by college business units according to field investigation, scientific implementation, in the project implementation will put some specific tasks according to actual condition by the supplier to complete and conclude a contract for the specific project [7]. Business department puts forward the specific requirements to suppliers, sometimes provide related materials according to actual condition, sometimes provide specific teaching design script, etc.

In the research and development of specific projects to follow the process of project development. Curriculum development follows the ADDIE process. Requirements of curriculum content in the form of a detailed design of teaching. Output of the products from the course outline, question bank, electronic courseware, lesson plans text to provide the lecturer of auxiliary teaching manuals, student handbook, etc in content and form have clear, specific, detailed requirements and standards.

\section{Role of project management mode}

In project evaluation, project requirements need to be elaborated by review. Institute of project evaluation cannot be confined to the submitted to project development. The specific project application effect is the key. Implementation of the application effect of tracking, timely feedback and improvement. In addition, the reuse of the course number, number, life cycle, course content update mechanism become an important index of project review. Through scientific and effective project review relevance promotion project achievements, so as to achieve the ultimate goal of improving individual and organizational performance.

\section{COMMON FEATURE ANALYSIS}

Corporate universities by project management mode to improve the institutionalized form, scientific and effective mechanism to ensure the quality and efficiency of corporate universities operation, project management process reflects the enterprise of the university of system, mechanism, value concept and culture, the core management idea which embodies the enterprise management. Project management mode is the enterprise university operation management mode of important, it makes the enterprise university operation management more scientific and efficient, it has standardized standardized unity mature process, strict quality requirements, can be effective for the entire quality monitoring and feedback in time, ensure the quality, efficiency and cost effective to ensure process optimization and system, the optimal results.

Budget allocation model show that parent companies willing to university funding for the enterprise. Corporate universities has investment value this view is illustrated. Corporate universities in the mother's enterprises has an important strategic status and role [8]. Corporate university knowledge production service has provided an alternative. Corporate universities through market outsourcing to replace the hard. Corporate university is an important production department of enterprise knowledge elements. Corporate universities is of great value. Corporate universities has considerable input-output efficiency, rather than a dispensable consumer sector, cost department. Budget allocation model, therefore, the essence of which is reflected by the mother enterprise recognition of the core value of corporate universities, ability.

Start formal recognition degree programs have become some of the modern enterprise of the university of development goals [9]. Only officially endorsed qualifications, can achieve the level of "university". Formal recognition seems to become a modern enterprise of the university of "entry". Through the case it is not hard to see, however, corporate universities to pursue the purpose of the approval certificate, causes each are not identical. Some schools offer approval manager education helps parent customers expand their business, enterprise development, is also based on the enterprise in the field of consulting business proprietary knowledge manager to provide education services. The enterprise the purpose of university is to realize the value of knowledge, and not for the parent companies to provide education and training services. So strictly speaking its not corporate universities, but as a knowledge-based enterprises can directly create value of the specific business profits. Some enterprises developed at the university college application and through formal education qualification approved by the purpose is to satisfy the force of the industry, namely professional jobs require continuing education credits. At the same time also helps to enhance the value of education and training, education training market. Part of the college is affiliated to the leading industry in the development of innovative companies. Itself has a strong scientific research strength, in the forefront of the development of science and technology, leading the industry of science and technology innovation, also natural authoritative in terms of education scientific research, business use of the education of scientific research resources not only cultivate reserve for the development of high-tech talent. And promote the high-tech innovation research and development. Thus, officially endorsed the education qualification, development degree programs are based on the actual situation of enterprise itself and the actual needs, i.e., or for enterprise has a certain input and output efficiency, or the enterprise itself has the corresponding strength or advantage. Without regard to their own actual situation and actual need blind pursuit, will become the myth of corporate university practice development [10]. For some companies to obtain formal education qualification approved by the need to pay the huge cost, even beyond the ability of the enterprise, that become the burden of the enterprise. Corporate universities, therefore, is the pursuit of the purpose of the approval certificate, because each are not identical, but is to serve the enterprise own development; Whether to start a formal degree programs should be approved by the mother according to the actual situation of enterprise itself and the actual demand.

Corporate universities to strengthen the profitability, the pursuit of a profit center, is essentially a concentrated reflection of enterprise management concept, embodied in: corporate universities focus on cost efficiency, pay attention to input and output efficiency; Corporate universities the pursuit of excellence quality, strengthening 
its core competencies and value. Corporate universities with service consciousness, innovation consciousness, market consciousness, competition consciousness, brand consciousness, etc. Therefore, the enterprise university improved profitability, the pursuit of a profit center is essentially a concentrated reflection of enterprise business philosophy. But corporate universities cannot excessive pursuit of a profit center, especially complete for-profit profit center. Once the enterprise university become completely for-profit profit center, it is equivalent to enterprises create value for matrix a profit

Based on the practical investigation and research, the enterprise at the university of one-sided pursuit of a profit center, there are the following reasons:

(1) corporate universities are facing the crisis of the survival and development. Due to the status of knowledge elements in enterprise production practice effect is not significant, business-to-business university does not have a material requirements, the lack of an irreplaceable core ability and value. When enterprise development crisis, corporate universities could become the burden of the enterprise. So corporate universities needs to prove his value, improve the quality of service, and have a certain market competitiveness, and even want to become a profit center, can be self-sufficient, on the basis of the enterprise to create value for the matrix profits.

(2) corporate university evaluation is not scientific and perfect. The value of corporate universities are easy to be ignored. Because the enterprise services at the university of matrix and matrix enterprise to create the value of the lack of scientific and mature measure system. Especially the value of human capital development are difficult to quantify for specific financial indicators. At the same time, corporate universities recessive value are easy to be neglected, such as morale, strengthen the cohesion, the construction of enterprise culture, etc. University of these enterprises lack of scientific evaluation of input and output benefits. Corporate universities own lack of core competence and value at the same time, will naturally lead to maternal enterprises ignore the role of the university, even think that university is completely cost department.

Emphasize the project management process and the integration of production practice, with various functional departments, business departments, and each link of production process, pay attention to actual effect of the development and application of project, manifested the enterprise university and the integration of the production practice of the internal logic. Project management mode, therefore, is the enterprise university operation management mode of important, the core management idea which embodies the enterprise management, manifested the enterprise university and the integration of the production practice of the internal logic.

\section{CONCLUSIONS}

In the modern society, the college and the enterprise are common. There is great difference between companies and universities in the nature, function and value pursuit. The function of university is passing on culture, cultivating talents. The pursuit of enterprise is to make a profit. The corporate universities and enterprise's production practice is the fusion of each other. The corporate university learning content is relatively more specific. The enterprise university learning programs and training products are mostly specificity, customized. The certification effectiveness of corporate university project that has some limitations. College and Enterprise is common in contemporary society. In this article, the enterprise financing pattern are analyzed, and the project management mode of university are studied; The common features of universities and corporations is discussed. The research of operation mode of corporate universities shows that: The financing pattern of corporate universities is the core of the enterprise university operation mechanism; The operating of corporate universities mainly on project management mode; Universities and corporations have common features, and the development of the corporate university is inevitable. The cooperation of corporate universities and the institutions of higher education is very important for our country industry talents training.

\section{REFERENCES}

[1] Song Xiling. Based on the perspective of adult education enterprise development research at the university of $[\mathrm{J}]$. Journal of hubei university adult education college, 2012, (10).

[2] Wu Feng. Based on the theory of enterprise model of human fields. Modern distance education research [J]. 2012, (3) : 75 - a - 79.

[3] Zhang Jing. Enterprise university research [M]. Beijing: economic science press, 2011 (8) : 27.

[4] Wu Feng, the silver. And the trend of development of the enterprise to study research field. The higher engineering education research [J]. 2012, (4) : November 16.

[5] Gao Qin and Long Yong, chang-lin ma, wen-liang guan. Mechanical and electrical integration of liquid system modeling and simulation technology [M]. Beijing: electronic industry press. 2012.

[6] Wu Feng. Enterprises to study research, based on the perspective of learning innovation [M]. Beijing: Beijing humanism publishing house. 2013.

[7] Allen, Mark. Corporate Universities. Globalization and Greater Sophistication[J]. Journal of International Management Studies,2010, 5(1): 48-53.

[8] LuiAbel. Exploring the corporate university phenomenon: Development and implementation of a comprehensive survey [J].human resource development quarterly. 2012. 23 (1) :26-31.

[9] Xue Song li. Enterprises from four different point of view to study [J]. Engineering machinery today, 2009, (12) : 124-126.

[10] Allen, Mark. Corporate Universities: Globalization and Greater Sophistication[J]. Journal of International Management Studies, 2010,5(10):48-53. 